\title{
OCCURRENCE OF MONILIFORMIN IN CEREALS
}

\author{
Bojana Đ. Radić*1 ${ }^{1}$, Jovana J. Kos ${ }^{1}$, Sunčica D. Kocić Tanackov², Elizabet P. Janić Hajnal', \\ Anamarija I. Mandić ${ }^{1}$ \\ ${ }^{1}$ University of Novi Sad, Institute of Food Technology, 21000 Novi Sad, \\ Bulevar cara Lazara 1, Serbia \\ ${ }^{2}$ University of Novi Sad, Faculty of Technology, 21000 Novi Sad, \\ Bulevar cara Lazara 1, Serbia
}

\author{
${ }^{*}$ Corresponding author: \\ Phone: +381214853754 \\ Fax: +38121450725 \\ E-mail address: bojana.radic@fins.uns.ac.rs
}

\begin{abstract}
In many parts of the world, the major cereal crops (maize, wheat, barley, rye and oats) are particularly susceptible to infection by Fusarium species. Moniliformin (MON) is a mycotoxin produced by Fusarium species, most often F. proliferatum, F. avenaceum and F. subglutinans. The occurrence of MON has been recorded worldwide, with the highest detected value of $530 \mathrm{mg} / \mathrm{kg}$ in maize intended for human consumption. Limited information on toxicity in experimental and farm animals indicates haematotoxicity and cardiotoxicity as the main damaging effects of MON on human health. Its stability and fate during processing has also been poorly studied, so the degree of consumer's exposure to MON is still uncertain.

This review summarizes available information on the MON chemistry, toxicity, its worldwide occurrence in cereals, methods of analysis and the potential methods for its decontamination in food and feed.
\end{abstract}

Key words: moniliformin, toxicity, food, feed, decontamination

\section{INTRODUCTION}

Food and feed monitoring for the appearance of mycotoxins from the genus Fusarium continues to attract world attention and in recent years has been a subject of extensive research (Summerell, 2019; Bertero et al., 2018; Bryła et al., 2018; Fraeyman et al., 2017). Factors that contribute to the development of Fusarium include humidity, temperature, aeration and substrate type (Stanciu et al., 2015). The genus Fusarium involves several species which are important pathogens of maize and small grains. Two main diseases of grains caused by Fusarium are
Fusarium head blight of small grains (primarily wheat, barley, and oats) and Fusarium ear rot of maize (Jestoi, 2008). Although data on Fusarium mycotoxins, such as trihotecene and zearalenone are very well documented, there are limited data on toxicity, occurrence and levels of contamination of other metabolites of $\mathrm{Fu}$ sarium species, such as moniliformin (MON).

MON is a mycotoxin produced by nearly 40 different Fusarium species, mainly $F$. proliferatum, F. avanaceum, F. subgluti- 
nans, F. tricinctum, F. verticillioides, F. anthophilum (Peltonen et al., 2010) and one Penicillium species (Penicillium melanoconidium) (Hallas-Møller et al., 2016). Among the most powerful producers of MON, $F$. subglutinans and $F$. proliferatum prevail in maize typically grown in warm climatic areas of Europe, while F. avenaceum and $F$. tricinctum are mainly occurring in small-grain cereals, primarily in moderate regions as Scandinavia (Peltonen et al., 2010). The optimal conditions for moniliformin biosynthesis by $F$. subglutinans and $F$. avanaceum are temperatures between $25-30{ }^{\circ} \mathrm{C}$ and water activity $\left(\mathrm{a}_{\mathrm{w}}\right)$ of minimum 0.90 (Kostecki et al., 1999). MON was found in cereals such as wheat, oats, rice, rye, barley, and triticale, while the greatest contamination was found in maize samples (Jestoi, 2008). In the recent European Food Safety Authority (EFSA) report (2018) it was concluded that there is a large uncertainty about risk assessment of MON in human and farm animals. Furthermore, only several experiments indicate moderate heat stability of MON during thermal food processing (Scott and Lawerence, 1987; PinedaValdes and Bullerman, 2000; PinedaValdes et al., 2002; Pineda-Valdes et al., 2003). Given the lack of data related to MON, further researches of its toxicity, occurrence and behavior under different food processing conditions are necessary (EFSA, 2018).

\section{Chemical structure and physicoche- mical properties of MON}

MON (Fig. 1) is a polyketide mycotoxin with low molecular weight $\left[\mathrm{C}_{4} \mathrm{H}_{2} \mathrm{O}_{3}\right.$, IUPAC: 3-hydroxycyclobut-3-ene-1,2-dione]. It is a polar, strong acid with a pKa value of 0.88 , also known as semisquaric acid. Because of the low pKa of the free acid, in the nature MON occurs as the sodium or potassium salt (EFSA, 2018).

MON is soluble in water and polar solvents. The UV absorbance of MON has a maximum at $227 \mathrm{~nm}$ and a shoulder at $258 \mathrm{~nm}$ in distilled water, with extinction coefficients of $19,900 \mathrm{M}^{-1} \mathrm{~cm}^{-1}$ and 5,400 $\mathrm{M}^{-1} \mathrm{~cm}^{-1}$, respectively (Sydenham et al., 1996). The melting point for the free acid is $158^{\circ} \mathrm{C}$ and for the sodium and potas- sium salts above $320{ }^{\circ} \mathrm{C}$ (Cole and Cox, 1981).

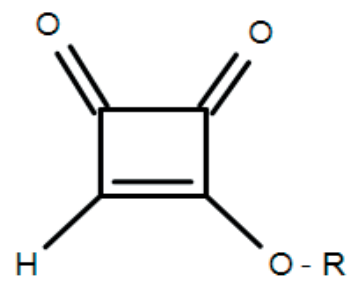

R: H (free acid, $98 \mathrm{~g} / \mathrm{mol}$ ), $\mathrm{Na}$ (sodium salt, $120 \mathrm{~g} / \mathrm{mol}, \mathrm{K}$ (potassium salt, $136 \mathrm{~g} / \mathrm{mol}$ )

Figure 1. Chemical structure of MON

\section{TOXICITY OF MON}

The mode of action of MON is associated with inhibition of the incorporation of pyruvate into the tricarboxylic acid cycle (TCA). Apart from that, MON inhibits the oxidation of intermediates of the TCA (Thiel, 1978).

Acute toxicity - MON has an acute toxicity at a level comparable to other mycotoxins derived from the Fusarium genus, such as T-2 toxin and diacetoxysirpenol type A trichothecenes (Sørensen et al., 2007). The specific symptoms of acute toxicity of MON are respiratory stress, muscle weakness, myocardial degeneration and certain evidence of histopathological changes in organs such as pancreas, lungs and kidneys accompanied by vomiting and death (Jonsson et al., 2013). Cardiac changes induced by MON have also been reported in several earlier studies (Kriek et al., 1977; Thiel, 1978; Morgan et al., 1999). Table 1 gives the results of some MON acute toxicity studies $\left(L^{2} D_{50}\right)$ in different animals. LD $_{50}$ values are defined as lethal doses of moniliformin that kill $50 \%$ of the test animals during the observation period.

Subacute, subchronic and chronic toxicity - Subacute toxicity study (Jonsson et al., 2015) in rats predicted LOAEL (lowest-observed-adverse-effect level) of $3 \mathrm{mg} / \mathrm{kg} \mathrm{BW}$. Indications of cardiotoxicity were observed at $9 \mathrm{mg} \mathrm{MON} / \mathrm{kg}$ BW per day and cardiotoxicity was observed at $15 \mathrm{mg} \mathrm{MON} / \mathrm{kg}$ BW per day. Furthermore, to date only one study (Kriek et al., 1977) has been published regarding subchronical toxicity of MON on rats. According to this study MON showed MON 
Table 1.

Acute toxicity $\left(\mathrm{LD}_{50}\right)^{*}$ of MON in different animal models

\begin{tabular}{cccc}
\hline Species & Route of exposure & $\begin{array}{c}\text { LD }_{50} \\
(\mathrm{mg} / \mathrm{kg} \mathrm{BW})\end{array}$ & Reference \\
\hline Broiler chicken & Oral & 1.38 & Allen et al. (1981) \\
1-day old chicken & Crop intubation & 5.4 & Burmeister et al. (1979) \\
Duckling & Intubation & 3.7 & Kriek et al. (1977) \\
Mice (F/M) & Intraperitoneal & $20.9 / 29.1$ & Bryden et al. (2001) \\
Mice & Oral & 47.6 & Burmeister et al. (1980) \\
Mink & Intraperitoneal & $2.2-2.8$ & Morgan et al. (1999) \\
Rats $(\mathrm{F} / \mathrm{M})$ & Oral & $41.6 / 50.0$ & Krieck et al. (1977) \\
Rats & Oral & 25.0 & Jonsson et al. (2013)
\end{tabular}

*Lethal dose $50 \%$

$F$ - female; $M$ - male

$B W$ - body weight

indications of cardio toxicity at $17 \mathrm{mg} \mathrm{BW}$ per day, while mortality was observed at $32.5 \mathrm{mg} \mathrm{MON} / \mathrm{kg}$ BW per day. Until today, there are no reports related to chronic effects of MON.

Carcinogenicity and genotoxicity According to the last available information for the carcinogenicity of MON, the International Agency for Research on Cancer (IARC) classified it in the 3rd group of carcinogenic compounds, due to the insufficient relevant studies (IARC, 2006). As far as genotoxicity is concerned, in vitro study shows that MON causes chromosomal damage (Knasmüller et al., 1997). However, there is no genotoxicity data in vivo, up to date.

Reproductive and developmental toxicity - Morgan et al. (1998) reported that long-term exposure to $F$. fujikuroi culture material containing $17 \mathrm{mg} \mathrm{MON} / \mathrm{kg}$ was not lethal to adult female mink, but resulted in significant neonatal mortality and reduced offspring body weight. There is no teratogenic effects of MON in experimental animals (mouse and 1-day old chicken) (Hayes and Hood, 1974; Burmeister et al., 1979).

Human studies - MON has been suggested as one of the etiological factors of Keshan disease, even if a clear correlation is lacking. Keshan disease is a dilated cardiomyopathy closely related to a diet deficient in the mineral selenium (Sørensen et al., 2007).

\section{OCCURRENCE OF MON IN CEREALS}

The numerous European countries (Table 2) reported the incidence of MON in cereals, and furthermore the greatest numbers of published data are related to the occurrence of MON in maize samples. The maximum level of MON recorded in maize $(530 \mathrm{mg} / \mathrm{kg})$ was detected in Fusariumdamaged maize in Poland (Chelkowski et al., 1987).

In 1991, Sharman et al. published an overview of the data on the occurrence of MON in cereal samples from worldwide sources, including some European countries (Italy, Poland, Netherlands and UK). This paper reported the contamination of maize, oats, wheat, rye and triticale with MON (the maximum concentration of $0.847 \mathrm{mg} / \mathrm{kg}$ ). In addition to cereals, MON was also detected in asparagus spears (Knaflewski et al., 2008) and apples with signs of wet apple core rot in Poland (Sørensen et al., 2009).

In the recent study, Herrera et al. (2017) published an overview on data about the occurrence of MON in cereal-based food samples collected in the Netherlands and Germany. MON was not detected in bread samples $(n=32)$. Of all analyzed wheat flour samples $(n=22)$, only one was contaminated with MON at level of 0.011 $\mathrm{mg} / \mathrm{kg}$. Seven of 25 examined pasta samples contained MON at levels around $0.010 \mathrm{mg} / \mathrm{kg}$. MON occurred in eight out of 
23 maize products at the levels of 0.012 $0.207 \mathrm{mg} / \mathrm{kg}$. Barthel et al. (2018) analyzed 39 samples of popcorn maize kernels $(n=21)$, maize meal $(n=14)$ and semolina $(n=4)$ from the Bavarian market (Germany). The samples originated from Germany $(n=8)$, Italy $(n=3)$, Turkey $(n=2)$, France $(n=2)$ and other European countries $(n=6)$. The origin of 18 samples was not indicated. The rate of contamination with MON was very high (97\%) with concentrations ranging from 0.002 to $0.847 \mathrm{mg} / \mathrm{kg}$.

In the recent Serbian study, 190 maize samples were analyzed. Samples were collected during harvest in the Northern Serbian province of Vojvodina over three years period (Jajić et al., 2019). MON was present in more than $90 \%$ of the 2016 maize harvest samples $(n=73)$, except in the West-Bačka region (50\%). Mean levels of MON ranged from 0.19 (West-Bačka) to $0.920 \mathrm{mg} / \mathrm{kg}$ (Srem). The maize samples $(n=72)$ from the 2017 harvest had more than $57 \%$ of samples contaminated with MON. The mean levels ranged from 0.179 (South-Bačka) to $0.499 \mathrm{mg} / \mathrm{kg}$ (WestBačka). Furthermore, MON was detected in more than $47 \%$ of the maize samples $(n=45)$ harvested in 2018. The mean levels ranged from 0.034 (North-Bačka) to $0.199 \mathrm{mg} / \mathrm{kg}$ (South-Bačka). The authors came to the conclusion that high precipitation levels during June 2018 in the South-Bačka and South-Banat regions and during July 2018 in South-Bačka resulted in obtaining the highest mean levels of MON. Further, stepwise regression showed (with 95\% confidence level) that air temperatures from May to August resulted in statistically significant differences in MON levels.

Environmental factors such as rain and temperature greatly affected the prevalence of MON in analyzed cereals from Finland (Jestoi and Kokkonen, 2008), Norway (Uhlig et al., 2004) and Italy (Scarpino et al., 2013). Lindblad et al. (2013) investigated the effect of vegetation season period on the MON contamination in wheat from Sweden. Higher levels of MON were detected in spring wheat in relation to winter wheat. However, MON was recorded at lower concentrations in organic wheat from Norway compared to conventional (Bernhoft et al., 2010). Although there are several species able to produce MON on a wide variety of hosts, the main problem in Europe is strongly linked to the presence of $F$. subglutinans in the maize ear rot complex and $F$. avenaceum in Fusarium head blight of wheat (Jestoi, 2008).

MON levels were also analyzed in feed ingredients and compound feeds (Table 2). Scudamore et al. (1998) examined 67 samples of maize gluten and milled maize products, destined for incorporation into animal feedstuffs in the United Kingdom. Analysis showed that $61 \%$ of samples contained MON in concentrations higher than $4.6 \mathrm{mg} / \mathrm{kg}$. Results from Slovakia indicate that $52 \%$ of poultry feed samples $(n=50)$ were contaminated with MON (concentration range from 0.042 to 1.214 $\mathrm{mg} / \mathrm{kg}$ ) (Labuda et al., 2005).

Several studies carried out in Africa, America, Asia and Oceania reported the incidence of MON in cereals (Table 2).

Thiel et al. (1982) first recorded the natural occurrence of MON at very high level of 25 $\mathrm{mg} / \mathrm{kg}$ in visibly infected maize kernels in Transkei, South Africa. Although most African countries have a climate characterized by high humidity and high temperature, MON has been considered as an important maize contaminant in the cooler production areas of South Africa (Thiel et al., 1982). Boutigny et al. (2012) reported that Fusarium subglutinans is the Fusarium species most commonly associated with maize, especially in colder areas of South Africa and that MON was detected in $62 \%$ of maize samples collected in 2008-2009, with a maximum level of 1.53 $\mathrm{mg} / \mathrm{kg}$. The first report of the natural occurrence of MON in maize in the United States was conducted by Thiel et al. (1986) and detected MON concentrations were up to $2.82 \mathrm{mg} / \mathrm{kg}$. Gutema et al. (2000) conducted a survey in commercial maize samples from different regions of the United States and detected MON concentrations were up to $0.77 \mathrm{mg} / \mathrm{kg}$. In the same study, levels up to $0.86 \mathrm{mg} / \mathrm{kg}$ were observed in maize-based retail food products, including maize meal, maize grits, maize masa mix, muffin mix, maize bread 
mix, self-rising maize mix, easy mix and maize flour. The first report from Brazil shows that MON is not a common contaminant of maize planted within the state (Leoni and Soares, 2003). New data reported contamination of sorghum grains intended for animal consumption in Argentina, with MON at levels ranging from 0.363 to $0.914 \mathrm{mg} / \mathrm{kg}$ (Pena et al, 2019). There is a lack/shortage of research in Asian and Oceanian countries on the occurrence of MON in cereals.

Table 2

Worldwide contamination of cereals with MON

\begin{tabular}{|c|c|c|c|c|}
\hline Country & $\begin{array}{l}\text { Food/ } \\
\text { Feed }\end{array}$ & Commodity & $\begin{array}{c}\text { Concentration } \\
\text { range } \\
(\mathrm{mg} / \mathrm{kg})\end{array}$ & References \\
\hline \multicolumn{5}{|c|}{ Europe } \\
\hline \multirow[t]{3}{*}{ Austria } & Food & Maize & n.a./0.02 & Lew et al. (1991) \\
\hline & Food & Maize crops & n.a./0.8 & Lew et al. (2001) \\
\hline & Feed & Maize & $0.16 / 1.03$ & Parich et al. (2003) \\
\hline Denmark & Feed & Maize & $0.001 / 001$ & Sørensen et al. (2007) \\
\hline \multirow[t]{2}{*}{ Finland } & Food & Cereal samples & $<0.02 / 0.81$ & Jestoi et al. (2004) \\
\hline & - & Cereal samples & $<0.02 / 0.85$ & Jestoi and Kokkonen (2008) \\
\hline \multirow[t]{3}{*}{ Germany } & Food & Maize & $<0.08 / 0.65$ & Thalmann et al. (1985) \\
\hline & Food & Cereal samples & $<0.0007 / 0.13$ & Von Bargen et al. (2012) \\
\hline & Feed & Maize & n.a./3.33 & Goertz et al. (2010) \\
\hline Italy & Feed & Maize & $<0.001 / 2.61$ & Scarpino et al. (2013) \\
\hline \multirow[t]{3}{*}{ Netherlands } & Feed & $\begin{array}{l}\text { Winter wheat - } \\
\text { preharvest }\end{array}$ & $0.005 / 0.1$ & Van der Fels-Klerx et al. (2012) \\
\hline & Feed & $\begin{array}{l}\text { Winter wheat - at } \\
\text { harvest }\end{array}$ & $0.007 / 0.33$ & Van der Fels-Klerx et al. (2012) \\
\hline & Feed & Maize cobs & $<0.05 / 0.33$ & Van Asselt et al. (2012) \\
\hline \multirow[t]{5}{*}{ Norway } & Feed & Cereal samples & $<0.13 / 0.95$ & Uhlig et al. (2004) \\
\hline & Food & Organic wheat & $<0.04 / 0.25$ & Bernhoft et al. (2010) \\
\hline & Food & Conventional wheat & $<0.04 / 0.34$ & Bernhoft et al. (2010) \\
\hline & Food & Cereal samples & n.a./0.52 & Uhlig et al. (2013) \\
\hline & Food & Oats & n.a./0.17 & Ivanova et al. (2017 \\
\hline \multirow[t]{12}{*}{ Poland } & Food & Maize & $30 / 530$ & Chelkowski et al. (1987) \\
\hline & Food & Wheat & $0.5 / 17$ & Sharman et al. (1991) \\
\hline & Food & Rye & $6.1 / 12$ & Sharman et al. (1991) \\
\hline & Food & Triticale & $2.6-16$ & Sharman et al. (1991) \\
\hline & Food & Oats & $16 / 38$ & Sharman et al. (1991) \\
\hline & Food & Maize & $4.2 / 399$ & Sharman et al. (1991) \\
\hline & Food & Maize & $17 / 425$ & Logrieco et al. (1993) \\
\hline & Food & Wheat & $7.200 / 25.2$ & Lew et al. (1993) \\
\hline & Food & Triticale & $2.4 / 5.1$ & Lew et al. (1993) \\
\hline & Feed & Wheat & n.a./0.198 & $\begin{array}{c}\text { Grabarkiewicz-Szczesna et al. } \\
(2001)\end{array}$ \\
\hline & - & $\begin{array}{l}\text { Wheat with scab } \\
\text { symptoms }\end{array}$ & $<0.010 / 1.72$ & Tomczak et al. (2002) \\
\hline & Food & Wheat & n.a./0.3 & Kulik (2008) \\
\hline Serbia & - & Maize & $0.002 / 3.86$ & Jajić et al. (2019) \\
\hline Slovakia & Feed & Poultry feed & $<0.04 / 1.21$ & Labuda et al. (2005) \\
\hline \multirow[t]{3}{*}{ Sweden } & Food & Oats & $<0.02 / 0.22$ & Fredlund et al. (2013) \\
\hline & Food & Winter wheat & $<0.02 / 0.5$ & Lindblad et al. (2013) \\
\hline & Food & Spring wheat & $<0.02 / 2.08$ & Lindblad et al. (2013) \\
\hline Switzerland & Food & Maize-based & $<0.2 / 1.35$ & Noser et al. (2001) \\
\hline
\end{tabular}




\begin{tabular}{|c|c|c|c|c|}
\hline Country & $\begin{array}{l}\text { Food/ } \\
\text { Feed }\end{array}$ & Commodity & $\begin{array}{c}\text { Concentration } \\
\text { range } \\
(\mathrm{mg} / \mathrm{kg}) \\
\end{array}$ & References \\
\hline \multirow{6}{*}{$\begin{array}{l}\text { United } \\
\text { Kingdom }\end{array}$} & & products & & \\
\hline & Food & Ethnic food & $<0,01 / 0.03$ & FSA (2013) \\
\hline & Feed & Maize gluten & $<0.05 / 0.32$ & Scudamore et al. (1998) \\
\hline & Feed & Maize products & $<0.05 / 4.6$ & Scudamore et al. (1998) \\
\hline & Feed & Barley & n.a./0.045 & Edwards (2007) \\
\hline & Feed & Oats & n.a. $/<0.010$ & Edwards (2007) \\
\hline \multicolumn{5}{|c|}{ Africa } \\
\hline \multirow{4}{*}{ South Africa } & Food & Maize & $16 / 25$ & Thiel et al. (1982) \\
\hline & Food & Maize & $0.35 / 11.57$ & Sydenham et al. (1990) \\
\hline & Food & Maize & $0.32 / 0.39$ & Rheeder et at. (1994) \\
\hline & - & Maize & $<0.02 / 1.53$ & Boutigny et al. (2012) \\
\hline \multicolumn{5}{|c|}{ America } \\
\hline Argentina & Feed & Sorghum grains & $0.36 / 0.91$ & Pena et al. (2019) \\
\hline \multirow{2}{*}{$\begin{array}{l}\text { Arizona, } \\
\text { California, } \\
\text { Nebraska, and } \\
\text { Ohio }\end{array}$} & Food & Maize & $<0.03 / 0.77$ & Gutema et al. (2000) \\
\hline & & $\begin{array}{l}\text { Maize-based } \\
\text { products }\end{array}$ & $<0.03 / 0.86$ & Gutema et al. (2000) \\
\hline Brazil & Food & Maize & - & Leoni and Soares (2003) \\
\hline Canada & Food & Maize & $0.05 / 0.2$ & Scott and Lawrence (1987) \\
\hline Not specified & Feed & Maize & n.a./2.82 & Thiel et al. (1986) \\
\hline \multicolumn{5}{|c|}{ Asia } \\
\hline \multirow[t]{4}{*}{ China } & Food & Rice & n.a./0.25 & Ji (1991) \\
\hline & Food & Maize & n.a./0.26 & Ji (1991) \\
\hline & Food & Rice & $0.07 / 0.27$ & Yu et al. (1995) \\
\hline & Food & Maize & $0.05 / 1.12$ & Yu et al. (1995) \\
\hline \multicolumn{5}{|c|}{ Oceania } \\
\hline New Zealand & - & Maize & n.a./64 & Hussein et al. (1991) \\
\hline
\end{tabular}

\section{DETERMINATION OF MON CONTENT IN CEREALS}

Analytical methods commonly consist of MON extraction from the samples with an extraction solvent, usually followed by a sample purification step and a final detection/quantification step of MON by convenient techniques (Scarpino et al., 2013).

Extraction of MON is generally carried out with acetonitrile-water solutions (84-95\% acetonitrile). Purification steps may include the use of strong anion exchange columns or other solid-phase extraction columns including MycoSep ${ }^{\mathrm{TM}}$ columns (EFSA, 2018).

Several analytical methods for the quantification of MON have been published so far: ion-pair high-performance liquid chromatography (HPLC) with UV detection, fluorescence detection or detection by atmospheric pressure chemical ionizationmass spectrometry, ion chromatography (IC), thin-layer chromatography (TLC), capillary electrophoresis coupled to diode array detector (CE-DAD), gas chromatography-mass spectrometry after derivatization (GC-MS), liquid chromatography coupled to ultraviolet detection (LC-UV) and currently used method: liquid chromatography coupled with tandem mass spectrometry (LC-MS/MS). Besides methods specifically developed for MON analysis (single analyte methods), MON has also been a part of multi-methods for mycotoxin analysis by LC-MS/MS. However, none of the mentioned analytical methods for MON have been validated in interlaboratory studies. Also, certified reference materials are not available for MON, but calibrants are commercially available (EFSA, 2018). 


\section{DECONTAMINATION OF MON}

Physical methods - MON is stable in food processing that occurs in neutral or acidic conditions, but is unstable in food processing in alkali conditions (PinedaValdes and Bullerman, 2000). In ground maize and ground wheat with the addition of $\mathrm{MON}$ at $1 \mathrm{mg} / \mathrm{kg}$ levels, a moderate degradation was observed by heating at 50 , 100 and $150{ }^{\circ} \mathrm{C}$ for $0.5-2 \mathrm{~h}$, e.g. at $150{ }^{\circ} \mathrm{C}$ about $38 \%$ and about $15 \%$ of MON remained in maize and wheat, respectively (Scott and Lawerence, 1987). Autoclaving at $121{ }^{\circ} \mathrm{C}$ for $65 \mathrm{~min}$ of creamed maize for infants and cream style maize and roasting at $218{ }^{\circ} \mathrm{C}$ for $15 \mathrm{~min}$ of maize meal, all three spiked with $5 \mathrm{mg} \mathrm{MON} / \mathrm{kg}$, showed MON reductions of $10 \%, 23 \%$ and $45 \%$, respectively (Pineda-Valdes et al., 2003). However, heating of naturally contaminated maize sample with a MON content of $1.4 \mathrm{mg} / \mathrm{kg}$ at $\mathrm{pH} 10$ for $1 \mathrm{~h}$ at $175{ }^{\circ} \mathrm{C}$ showed complete reduction of MON (Pineda-Valdes et al., 2002). Overall, under the conditions tested for baking, autoclaving, frying, roasting and extrusion, MON showed thermal stability similar to or greater than other Fusarium mycotoxins such as deoxynivalenol and fumonisin B1 (Pineda-Valdes et al., 2003).

Chemical methods - As with many other toxins, ozonization is also an effective method in detoxification of MON due to opening the 4-C structure (Zhang and $\mathrm{Li}$, 1994). Zhang and Li (1997) also examined the detoxification of MON in grains and water. To reduce the content of MON in water, chlorinated lime, heating, activated carbon, ozone, microwave, and UV were tested. The chlorinated lime was selected as the most effective method for detoxification of $\mathrm{MON}$ in water. Furthermore, spray treatment with solution of $5 \% \mathrm{H}_{2} \mathrm{O}_{2}$ was the best method for detoxification of MON in grains.

Biological methods - Wu (1997) established an approach in the control of mycotoxins in animals by supplementing drinking water with the Poultry Aid Plus (PAP) formulation. PAP is a Lactobacillus acidophilus fermentation liquid formula intended for water application to reduce digestive stress in poultry. The application of PAP also reduces mortality and improves weight gain when poultry is fed with food contaminated with $F$. proliferatum. However, there is a different approach to the control of mycotoxins in plants. Duvick and Rood (1999) found that Ochrobactrum anthropi, isolated from moldy maize, capable of using MON as the only source of carbon and thus partially or completely degrades it in the process. The treatment can be done in field, pre-harvest, locally applying a suspension of bacteria on a plant or applying it post-harvest, on harvested grain.

\section{LEGISLATION}

Currently, there are no Regulations related to the maximum levels of MON in food and feed all over the world (EFSA, 2018).

\section{CONCLUSIONS}

Taking into account the lack of data on toxicity, occurrence and methods of reduction of MON, and therefore of food safety and protection of human and animal health, it is necessary to further collect data on the presence of this mycotoxin in food and feed. Further research should focus on maize and maize-based products, as well as other cereals and cerealbased products in which the presence of MON in high concentrations has been established so far. Studies on the ecology of the main fungi involved in the production of MON are also necessary.

\section{ACKNOWLEDGEMENTS}

This paper is a result of the research within the project TR31029 "Functional products based on cereals designed for people with metabolic disorders", financed by the Ministry of Education, Science and Technological Development, Republic of Serbia.

\section{REFERENCES}

1. Allen, N.K., Burmeister, H.R., Weaver, G.A., Mirocha, C.J. (1981). Toxicity of dietary and intravenously administered moniliformin to broiler chickens. Poultry Science, 60 (7), 14151417.

2. Barthel, J., Rapp, M., Holtmannspötter, H., Gottschalk, C. (2018). A rapid LC-MS/MS method for the determination of moniliformin and 
occurrence of this mycotoxin in maize products from the Bavarian market. Mycotoxin Research, 34 (1), 9-13.

3. Bernhoft, A., Clasen, P.E., Kristoffersen, A.B., Torp, M. (2010). Less Fusarium infestation and mycotoxin contamination in organic than in conventional cereals. Food Additives and Contaminants, 27 (6), 842-852.

4. Bertero, A., Moretti, A., Spicer, L., Caloni, F. (2018). Fusarium molds and mycotoxins: Potential species-specific effects. Toxins, 10 (6), 244.

5. Boutigny, A.L., Beukes, I., Small, I., Zühlke, S., Spiteller, M., Van Rensburg, B.J., Flett, B., Viljoen, A. (2012). Quantitative detection of Fusarium pathogens and their mycotoxins in South African maize. Plant Pathology, 61 (3), 522-531.

6. Bryden, W.L., Logrieco, A., Abbas, H.K., Porter, J.K., Vesonder, R.F., Richard, J.L., Cole, R.J. (2001). Other significant Fusarium mycotoxins. Paul E. Nelson Memorial Symposium, Saint Paul, Minnesota, Proceedings, pp. 360-392.

7. Bryła, M., Waśkiewicz, A., Ksieniewicz-Woźniak, E., Szymczyk, K., Jędrzejczak, R. (2018). Modified Fusarium mycotoxins in cereals and their products-metabolism, occurrence, and toxicity: an updated review. Molecules, 23 (4), 963.

8. Burmeister, H.R., Ciegler, A., Vesonder, R.F. (1979). Moniliformin, a metabolite of Fusarium moniliforme NRRL 6322: purification and toxicity. Applied and Environmental Microbiology, 37 (1), 11-13.

9. Burmeister, H.R., Grove, M.D., Kwolek, W.F. (1980). Moniliformin and butenolide: effect on mice of high-level, long-term oral intake. Applied and Environmental Microbiology, 40 (6), 1142-1144.

10. Chelkowski, J., Zajkowski, P., Zawadzki, M., Perkowski, J. (1987). Moniliformin, deoxynivalenol, 3-acetyldeoxynivalenol and zearalenone - Mycotoxins associated with corn cob fusariosis in Poland. Mycotoxin Research, 3 (1), 25-27.

11. Cole, R.J., Cox, R.H. (1981). Fusarium toxins. In Handbook of toxic fungal metabolites. Ed. R.J. Cole, Elsevier, Amsterdam, the Netherlands, pp. 893-910.

12. Duvick, J., Rood, T.A. (1999). U.S. Patent No. $6,001,638$. U.S. Patent and Trademark Office, Washington, DC.

13. Edwards, S. (2007). Investigation of Fusarium mycotoxins in UK barley and oat production. Project report No. 415. Home-Grown Cereals Authority.

14. (EFSA) European Food Safety Authority (2018). Scientific Opinion on the risks to human and animal health related to the presence of moniliformin in food and feed. EFSA Journal, 16 (3), 1-95, DOI: 10.2903/j.efsa.2018.5082.

15. Fraeyman, S., Croubels, S., Devreese, M., Antonissen, G. (2017). Emerging Fusarium and Alternaria mycotoxins: occurrence, toxicity and toxicokinetics. Toxins, 9 (7), 228.
16. Fredlund, E., Gidlund, A., Sulyok, M., Börjesson, T., Krska, R., Olsen, M., Lindblad, M. (2013). Deoxynivalenol and other selected Fusarium toxins in Swedish oats - Occurrence and correlation to specific Fusarium species. International Journal of Food Microbiology, 167 (2), 276-283.

17. (FSA) Food Standards Agency (2013). Mycotoxins in ethnic food. Food Survey Information Sheet 04/13. (Retrieved February 09, 2019 from

https://www.food.gov.uk/sites/default/files/multi media/pdfs/scienceresearch/fsis-mycotoxinsyear-3.pdf)

18. Goertz, A., Zuehlke, S., Spiteller, M., Steiner, U., Dehne, H.W., Waalwijk, C., Vries, I., Oerke, E.C. (2010). Fusarium species and mycotoxin profiles on commercial maize hybrids in Germany. European Journal of Plant Pathology, 128 (1), 101-111.

19. Grabarkiewicz- Szczesna, J., Kostecki, M., Golinski, P., Kiecana, I. (2001). Fusariotoxins in kernels of winter wheat cultivars field samples collected during 1993 in Poland. Food/Nahrung, 45 (1), 28-30.

20. Gutema, T., Munimbazi, C., Bullerman, L.B. (2000). Occurrence of fumonisins and moniliformin in corn and corn-based food products of US origin. Journal of Food Protection, 63 (12), 1732-1737.

21. Hallas-Møller, M., Nielsen, K.F., Frisvad, J.C. (2016). Production of the Fusarium mycotoxin moniliformin by Penicillium melanoconidium. Journal of Agricultural and Food Chemistry, 64 (22), 4505-4510.

22. Hayes, A.W., Hood, R.D. (1974). Mycotoxin induced developmental abnormalities. In Proceedings of the Western Hemisphere Nutrition Congress IV. Eds. P.L. White, N. Selvey (pp. 397-402). Publishing Sciences Group, Acton, Mass.

23. Herrera, M., Dam, R., Spanjer, M., Stoppelaar, J., Mol, H., Nijs, M., Lopez, P. (2017). Survey of moniliformin in wheat- and corn-based products using a straightforward analytical method. Mycotoxin Research, 33 (4), 333-341.

24. Hussein, H.M., Baxter, M., Andrew, I.G., Franich, R.A. (1991). Mycotoxin production by Fusarium species isolated from New Zealand maize fields. Mycopathologia, 113 (1), 35-40.

25. (IARC) International Agency for Research on Cancer (2002). Some traditional herbal medicine, some mycotoxins, naphthalene and styrene, IARC Monographs on the evaluation of carcinogenic risks to humans, Volume 82 , WHO, IARCPress, Lyon, France, pp. 169-345.

26. Ivanova, L., Sahlstrøm, S., Rud, I., Uhlig, S., Fæste, C.K., Eriksen, G.S., Divon, H.H. (2017). Effect of primary processing on the distribution of free and modified Fusarium mycotoxins in naturally contaminated oats. World Mycotoxin Journal, 10 (1), 73-88.

27. Jajić, I., Dudaš, T., Krstović, S., Krska, R., Sulyok, M., Bagi, F., Savić, Z., Guljaš, D., Stankov, A. (2019). Emerging Fusarium mycotoxins fusaproliferin, beauvericin, enniatins, and 
moniliformin in Serbian maize. Toxins, 11 (6), 357.

28. Jestoi, M. (2008). Emerging Fusarium-mycotoxins fusaproliferin, beauvericin, enniatins, and moniliformin - A review. Critical Reviews in Food Science and Nutrition, 48 (1), 21-49.

29. Jestoi, M., Kokkonen, M. (2008). "Uudet" Fusarium-mykotoksiinit suomalaisessa viljassa. Suomen Maataloustieteellisen Seuran Tiedote, 23, 1-7.

30. Jestoi, M., Rokka, M., Yli-Mattila, T., Parikka, P., Rizzo, A., Peltonen, K. (2004). Presence and concentrations of the Fusarium-related mycotoxins beauvericin, enniatins and moniliformin in Finnish grain samples. Food Additives and Contaminants, 21 (8), 794-802.

31. Ji, Z. (1991). Assay of moniliformin content in household grains from families in patients with Keshan disease. Zhonghua yi xue za zhi, 71 (1), 14-15.

32. Jonsson, M., Atosuo, J., Jestoi, M., Nathanail, A.V., Kokkonen, U.-M., Anttila, M., Koivisto, P., Lilius, E.-M., Peltonen, K. (2015). Repeated dose 28-day oral toxicity study of moniliformin in rats. Toxicology Letters, 233 (1), 38-44.

33. Jonsson, M., Jestoi, M., Nathanail, A.V., Kokkonen, U.M., Anttila, M., Koivisto, P., Peltonen, K. (2013). Application of OECD Guideline 423 in assessing the acute oral toxicity of moniliformin. Food and Chemical Toxicology, 53, 27-32.

34. Knaflewski, M., Golinski, P., Kostecki, M., Waskiewicz, A., Weber, Z. (2008). Mycotoxins and mycotoxin-producing fungi occurring in asparagus spears. Acta Horticulturae, 1(776), 183-190.

35. Knasmüller, S., Bresgen, N., Kassie, F., Mersch-Sundermann, V., Gelderblom, W., Zöhrer, E., Eckl, P.M. (1997). Genotoxic effects of three Fusarium mycotoxins, fumonisin B1, moniliformin and vomitoxin in bacteria and in primary cultures of rat hepatocytes. Mutation Research/Genetic Toxicology and Environmental Mutagenesis, 391 (1-2), 39-48.

36. Kostecki, M., Wisniewska, H., Perrone, G., Ritieni, A., Jerzy, P.G., Chelkowski, J., Logrieco, A. (1999). The effects of cereal substrate and temperature on production of beauvericin, moniliformin and fusaproliferin by Fusarium subglutinans ITEM-1434. Food Additives and Contaminants, 16 (9), 361-365.

37. Kriek, N.P.J., Marasas, W.F.O., Steyn, P.S., Van Rensburg, S.J., Steyn, M. (1977). Toxicity of a moniliformin-producing strain of Fusarium moniliforme var. subglutinans isolated from maize. Food and Cosmetics Toxicology, 15 (6), 579-587.

38. Kulik, T. (2008). Detection of Fusarium tricinctum from cereal grain using PCR assay. Journal of Applied Genetics, 49 (3), 305-311.

39. Labuda, R., Parich, A., Vekiru, E., Tancinová, D. (2005). Incidence of fumonisins, moniliformin and Fusarium species in poultry feed mixtures from Slovakia. Annals of Agricultural and Environmental Medicine, 12 (1), 81-86.

40. Leoni, L.A.B., Soares, L.M.V. (2003). Survey of moniliformin in corn cultivated in the state of
São Paulo and in corn products commercialized in the city of Campinas, SP. Brazilian Journal of Microbiology, 34 (1), 13-15.

41. Lew, H., Adler, A., Edinger, W. (1991). Moniliformin and the European corn borer (Ostrinia nubilalis). Mycotoxin Research, 7 (1), 71-76.

42. Lew, H., Adler, A., Edinger, W., Brodacz, W., Kiendler, E., Hinterholzer, J. (2001). Fusarium species and their toxins in Austrian maize. Bodenkultur, 52 (3), 199-207.

43. Lew, H., Chelkowskl, J., Wakulinski, W., Edinger, W. (1993). Moniliformin in wheat and triticale grain. Mycotoxin Research, 9 (2), 6671.

44. Lindblad, M., Gidlund, A., Sulyok, M., Börjesson, T., Krska, R., Olsen, M., Fredlund, E. (2013). Deoxynivalenol and other selected Fusarium toxins in Swedish wheat - Occurrence and correlation to specific Fusarium species. International Journal of Food Microbiology, 167 (2), 284-291.

45. Logrieco, A., Moretti, A., Ritieni, A., Chelkowski, J., Altomare, C., Bottalico, A., Randazzo, G. (1993). Natural occurrence of beauvericin in preharvest Fusarium subglutinans infected corn ears in Poland. Journal of Agricultural and Food Chemistry, 41 (11), 2149-2152.

46. Morgan, M.K., Fitzgerald, S.D., Rottinghaus, G.E., Bursian, S.J., Aulerich, R.J. (1999). Toxic effects to mink of moniliformin extracted from Fusarium fujikuroi culture material. Veterinary and Human Toxicology, 41 (1), 1-5.

47. Noser, J., Wenk, P., Sutter, A., Fankhauser, I., Hirschi, H. (2001). Fumonisine B1 und B2, moniliformin, beauvericin und zearalenon in mais auf dem Schweizer markt. Mitteilungen aus Lebensmitteluntersuchung und Hygiene, 92 (1), 90-103.

48. Parich, A., Boeira, L.S., Castro, S.P., Krska, R. (2003). Determination of moniliformin using SAX column clean-up and HPLC/DAD-detection. Mycotoxin Research, 19 (2), 203-206.

49. Peltonen, K., Jestoi, M., Eriksen, G. (2010). Health effects of moniliformin: a poorly understood Fusarium mycotoxin. World Mycotoxin Journal, 3 (4), 403-414.

50. Pena, G.A., Cavaglieri, L.R., Chulze, S.N. (2019). Fusarium species and moniliformin occurrence in sorghum grains used as ingredient for animal feed in Argentina. Journal of the Science of Food and Agriculture, 99 (1), 47-54.

51. Pineda-Valdes, G., Bullerman, L.B., 2000. Thermal stability of moniliformin at varying temperature, $\mathrm{pH}$, and time in an aqueous environment. Journal of Food Protection, 63, 1598-1601.

52. Pineda-Valdes, G., Ryu, D., Hanna, M.A., Bullerman, L.B. (2003). Reduction of moniliformin in corn by heat processing. Journal of Food Science, 68 (3), 1031-1035.

53. Pineda-Valdes, G., Ryu, D., Jackson, D.S., Bullerman, L.B. (2002). Reduction of moniliformin during alkaline cooking of corn. Cereal Chemistry, 79 (6), 779-782. 
54. Rheeder, J.P., Sydenham, E.W., Marasas, W. F.O., Thiel, P.G., Shephard, G.S., Schlechter, G.S., Stockenström, S., Cronje, D.E., Viljoen, J.H. (1994). Ear-rot fungi and mycotoxins in South African corn of the 1989 crop exported to Taiwan. Mycopathologia, 127 (1), 35-41.

55. Scarpino, V., Blandino, M., Negre, M., Reyneri, A., Vanara, F. (2013). Moniliformin analysis in maize samples from North-West Italy using multifunctional clean-up columns and the LCMS/MS detection method. Food Additives and Contaminants: Part A, 30 (5), 876-884.

56. Scott, P.M., Lawrence, G.A. (1987). Liquid chromatographic determination and stability of the Fusarium mycotoxin moniliformin in cereal grains. Journal of AOAC International, 70 (5), 850-853.

57. Scudamore, K.A., Nawaz, S., Hetmanski, M.T. (1998). Mycotoxins in ingredients of animal feeding stuffs: II. Determination of mycotoxins in maize and maize products. Food Additives and Contaminants, 15 (1), 30-55.

58. Sharman, M., Gilbert, J., Chelkowski, J. (1991). A survey of the occurrence of the mycotoxin moniliformin in cereal samples from sources worldwide. Food Additives and Contaminants, 8 (4), 459-466.

59. Sørensen, J.L., Nielsen, K.F., Thrane, U. (2007). Analysis of moniliformin in maize plants using hydrophilic interaction chromatography. Journal of Agricultural and Food Chemistry, 55 (24), 9764-9768.

60. Sørensen, J.L., Phipps, R.K., Nielsen, K.F., Schroers, H.J., Frank, J., Thrane, U. (2009). Analysis of Fusarium avenaceum metabolites produced during wet apple core rot. Journal of Agricultural and Food Chemistry, 5(4), 16321639.

61. Stanciu, O., Banc, R., Cozma, A., Filip, L., Miere, D., Mañes, J., Loghin, F. (2015). Occurrence of Fusarium mycotoxins in wheat from Europe - a review. Acta Universitatis Cibiniensis. Series E: Food Technology, 19 (1), 35-60.

62. Summerell, B.A. (2019). Resolving Fusarium: current status of the genus. Annual Review of Phytopathology, 57, 323-339.

63. Sydenham, E.W., Thiel, P.G., Marasas, W.F., Shephard, G.S., Van Schalkwyk, D. J., Koch, K. R. (1990). Natural occurrence of some Fusarium mycotoxins in corn from low and high esophageal cancer prevalence areas of the Transkei, Southern Africa. Journal of Agricultural and Food Chemistry, 38 (10), 19001903.

64. Sydenham, E.W., Thiel, P.G., Vleggaar, R. (1996). Physicochemical data for some selected Fusarium toxins. Journal of AOAC International, 79 (6), 1365-1379.

65. Thalmann, V.A., Matzenauer, S., GruberSchley, S. (1985). Survey on the occurrence of fusariotoxins in cereals. Berichte über Landwirtschaft, 63 (2), 257-272.

66. Thiel, P.G. (1978). A molecular mechanism for the toxic action of moniliformin, a mycotoxin produced by Fusarium moniliforme. Biochemical Pharmacology, 27 (4), 483-486.

67. Thiel, P.G., Gelderblom, W.C., Marasas, W.F., Nelson, P.E., Wilson, T.M. (1986). Natural occurrence of moniliformin and fusarin $\mathrm{C}$ in corn screenings known to be hepatocarcinogenic in rats. Journal of Agricultural and Food Chemistry, 34 (5), 773-775.

68. Thiel, P.G., Meyer, C.J., Marasas, W.F. (1982). Natural occurrence of moniliformin together with deoxynivalenol and zearalenone in Transkeian corn. Journal of Agricultural and Food Chemistry, 30 (2), 308-312.

69. Tomczak, M., Wisniewska, H., Stepien, L., Kostecki, M., Chelkowski, J., Golinski, P. (2002). Deoxynivalenol, nivalenol and moniliformin in wheat samples with head blight (scab) symptoms in Poland (1998-2000). European Journal of Plant Pathology, 108 (7), 625-630.

70. Uhlig, S., Eriksen, G., Hofgaard, I., Krska, R., Beltrán, E., Sulyok, M. (2013). Faces of a changing climate: Semi-quantitative multi-mycotoxin analysis of grain grown in exceptional climatic conditions in Norway. Toxins, 5 (10), 16821697.

71. Uhlig, S., Torp, M., Jarp, J., Parich, A., Gutleb, A.C., Krska, R. (2004). Moniliformin in Norwegian grain. Food Additives and Contaminants, 21 (6), 598-606.

72. Van Asselt, E.D., Azambuja, W., Moretti, A., Kastelein, P., De Rijk, T.C., Stratakou, I., Van Der Fels-Klerx, H.J. (2012). A Dutch field survey on fungal infection and mycotoxin concentrations in maize. Food Additives \& Contaminants, Part A, 29 (10), 1556-1565.

73. Van der Fels-Klerx, H.J., De Rijk, T.C., Booij, C. J.H., Goedhart, P.W., Boers, E.A.M., Zhao, C., Waalwijk, C., Mol, H.G.J., Van der Lee, T.A.J. (2012). Occurrence of Fusarium head blight species and Fusarium mycotoxins in winter wheat in the Netherlands in 2009. Food Additives and Contaminants, Part A, 29 (11), 1716-1726.

74. Von Bargen, K.W., Lohrey, L., Cramer, B., Humpf, H.U. (2012). Analysis of the Fusarium mycotoxin moniliformin in cereal samples using 13C2-moniliformin and high-resolution mass spectrometry. Journal of Agricultural and Food Chemistry, 60 (14), 3586-3591.

75. Wu, W. (1997). Counteracting Fusarium proliferatum toxicity in broiler chicks by supplementing drinking water with Poultry Aid Plus. Poultry Science, 76 (3), 463-468.

76. Yu, S.R., Liu, X. J., Wang, Y.H., Liu, J.(1995). A survey of moniliformin contamination in rice and corn from Keshan disease endemic and nonKSD areas in China. Biomedical and Environmental Sciences, 8 (4), 330-334.

77. Zhang, H., Li,J. (1994). Detoxification of moniliformin. Acta Microbiologica Sinica, 34 (2), 119123.

78. Zhang, H., Li, J. (1997). Detoxifying moniliformin in grains and water. Journal of Environmental Sciences, 9 (2), 215-220. 


\title{
ПОЈАВА МОНИЛИФОРМИНА У ЖИТАРИЦАМА
}

\author{
Бојана Ђ. Радић${ }^{* 1}$, Јована Ј. Кос ${ }^{1}$, Сунчица Д. Коцић Танацков ${ }^{2}$, Елизабет П. Јанић Хајнал ${ }^{1}$, \\ Анамарија И. Мандић ${ }^{1}$ \\ ${ }^{1}$ Универзитет у Новом Саду, Институт за прехрамбене технологије у Новом Саду, \\ 21000 Нови Сад, Булевар цара Лазара бр. 1, Србија \\ ${ }^{2}$ Универзитет у Новом Саду, Технолошки факултет Нови Сад, \\ 21000 Нови Сад, Булевар цара Лазара бр. 1, Србија
}

\begin{abstract}
Сажетак: Плесни из рода Fusarium често се јављају као контаминенти житарица (кукуруз, пшеница, јечам, раж и овас) широм света. Монилиформин (МOH) је микотоксин кога производе плесни рода Fusarium, најчешће $F$. proliferatum, $F$. subglutinans и $F$. avenaceum. Појава $\mathrm{MOH}$ је забележена широм света, при чему је највећа детектована вредност (530 мг/кг) забележена у кукурузу намењеном за људску потрошњу. Ограничене инфрормације о токсичности $\mathrm{MOH}$-а код експерименталних и домаћих животиња указују на његов потенцијални хематотоксични и кардиотоксични ефекат на здравље људи. Надаље, његова стабилност и понашање током прераде хране је такође слабо истражена, тако да се још увек не може са сигурношћу изразити степен ризика изложености потрошача.

Овај преглед сумира доступне информације о хемији $\mathrm{MOH}-\mathrm{a}$, токсичности, његовој појави у житарицама, методама детекције и потенцијалним методама за његову деконтаминацију у храни и храни за животиње.
\end{abstract}

Кључне речи: монилиформин, токсичност, храна, храна за животиње, деконтаминација

Received: 26 July 2019

Received in revised form: 10. September 2019

Accepted: 1 October 2019 